\title{
MARTIN HENGEL \\ A LIFE IN THE SERVICE OF CHRISTOLOGY
}

\author{
Roland Deines ${ }^{1}$
}

\begin{abstract}
Summary
While Martin Hengel has made a huge contribution to the study of early Judaism and emerging Christianity, his work can be seen to have a more specific focus. In celebration of Professor Hengel's eightieth birthday, this retrospective survey evaluates his work in and around the field of Christology, which can be seen as the centre and purpose of so much of his thinking.
\end{abstract}

What I mean, however, is that no greater thought has been conceived than that of the one God who, for the salvation of all, became a human being in Jesus of Nazareth and who gave up his life for all.

(Martin Hengel)

The task is delicate. How should a student introduce the work of his teacher when the teacher is distinguished from the student precisely by being superior to him in insight, knowledge and understanding? And let alone the work of Martin Hengel, which we find in numerous, magnificent volumes that are both extensive and rich in content, and beyond this in a plethora of articles that hardly permit an overview; ${ }^{2}$ a

1 Translated by Wayne Coppins and Simeon Zahl. For the German original, see R. Deines, 'Martin Hengel - Ein Leben Für Die Christologie', ThBeitr 37 (2006): 287 300. Translators' notes are marked by asterisks in the text.

2 The bibliography up to 2002 lists a total of 339 items and since then a whole series of lengthy articles and works has appeared. The notes that follow will only refer to some of these works and no attempt is made to provide a complete biography; for this, see J. Frey, 'Schriftenverzeichnis Martin Hengel 1959-1995', in Geschichte Tradition - Reflexion, FS M. Hengel, V. III: Frühes Christentum, ed. H. Lichtenberger (Tübingen: Mohr, 1996): 695-722; J. Frey, 'Schriftenverzeichnis Martin Hengel 19961998', in M. Hengel, Judaica, Hellenistica et Christiana: Kleine Schriften II (Tübingen: Mohr, 1999): 391-97; J. Frey, 'Schriftenverzeichnis Martin Hengel 19992002'; in M. Hengel, Paulus und Jakobus: Kleine Schriften III (Tübingen: Mohr, 
work whose richness is far from being exhausted and which when read again always evokes wonder at the breadth of learning contained therein. As his student, one realises in this rereading that what one thought was original to oneself already appears somewhere in the work of the teacher, in a footnote or passing remark, a secret undisturbed seed, as it were, which, unnoticed by the reader himself, grew up in his own thinking and brought forth fruit. To introduce the work of such a teacher can therefore only mean to stimulate colleagues, friends and skeptics to do something good for themselves and to make it their duty to work through a selection of Hengel regularly. This expands one's horizon and gives one a desire for more. Hengel's works are 'theological contributions' in the best sense of the word, ${ }^{*}$ which present intellectual and spiritual food in the sense of Hebrews 5:14. ${ }^{3}$

At the same time one is faced with the question of how the requested introduction should be organised: should it present the most important arguments chronologically or order them under broadly defined headings? Hengel himself describes his work as the effort 'to address contested topics and at the same time to penetrate into overlooked or neglected areas'. ${ }^{4}$ This self-characterisation, however, is more a

2002): 583-87. In what follows the three volumes of Hengel's shorter writings published thus far will be cited as KS I-III (KS I = Judaica et Hellenistica: Kleine Schriften I [Tübingen: Mohr, 1996]).

* The German word Beitrag (article; contribution) can also refer specifically to a contribution of food.

3 Since the first year of its publication subscribers to Theologische Beiträge have had ample opportunity to profit from the work of Hengel, who not only acted as editor but also published numerous articles in the journal as an author. These contributions often consisted of summaries of larger works in lecture format. A complete list up until 2001 appears in the issue dedicated to him on his seventy-fifth birthday: see K. Haacker, 'Martin Hengel zum 75. Geburtstag', ThBeitr 32 (2001): 289f. esp 290 n. 4. Since then has appeared M. Hengel, 'Die vier Evangelien und das eine Evangelium von Jesus Christus', ThBeitr 34 (2003): 18-33. One should also remember his sermons that appeared here, which would be worth collecting together with some of his other spiritual texts in a volume of their own. The information for ThBeitr is gathered in: J. Frey, 'Zur johanneischen Deutung des Todes Jesu', ThBeitr 32 (2001): 346-62: $348 \mathrm{f}$. n. 14 (cf. the complete index in: www.theologische-beitraege.de).

4 'Eine junge theologische Disziplin in der Krise' in Neutestamentliche Wissenschaft: Autobiographische Essays aus der Evangelischen Theologie, ed. EveMarie Becker (Tübingen / Basel: A. Francke): 18-29 (21). Additional biographical remarks appear in the numerous forewords of books written, edited or prompted by Hengel. From them much can be learned about the 'historical location' of this scholar. For another autobiographical text, see 'A Gentile in the Wilderness: My Encounter with Jews and Judaism' in Overcoming Fear Between Jews and Christians, ed. J. H. Charlesworth (New York: Crossroad, 1992): 67-83. Here he discusses at length his school days and his experience during the Nazi rule. Cf. also his 'speech of intro- 
description of the exterior. It is true, of course, that the 'fight for the truth' is a constant admonition in his discussions, and new discoveries from scholarship and research, especially if related to new sources, always find an open ear with him (for the Jubilar* what Paul accuses the Athenians of in Acts 17:21 applies in a good way). But scholarly curiosity and theological 'love of controversy' alone are hardly sufficient to explain the eros (and $\zeta \hat{\eta} \lambda \circ \varsigma$ ) with which Martin Hengel unflaggingly presents one study after another. The driving force (cf. the $\dot{\alpha} \nu \alpha \dot{\nu} \nu \eta$, of which Paul writes in 1 Cor. 9:16) and centre around which the life's work of the Jubilar circles is rather his struggle to discern the Christology of the New Testament.

In view of the thematically rich abundance of his works, which span from the time of Alexander the Great until far into the third century AD and in isolated cases even further, ${ }^{5}$ this claim may come as a surprise and perhaps even appear to some as reductionist. ${ }^{6}$ For who upon

duction' on the occasion of his reception to the Heidelberger Akademie der Wissenschaften (in: Jahrbuch der Heidelberger Akademie der Wissenschaften für das Jahr 1978 [Heidelberg: Winter, 1979]: 115-19); cf. also 'Erinnerungen. Ein Blick zurück in Dankbarkeit' in Festschrift zum 175-jährigen Bestehen der Zinzendorfschule Königsfeld im Jahr 1989: 78-80. Among others Friedrich Hänssler was a pupil with him at that time.

* Since this article has been written (and translated) for the purpose of honouring Martin Hengel on his eightieth birthday, we have retained the German Jubilar. This seems preferable to adopting the English 'birthday boy' or simply writing 'Hengel'.

5 It belongs to the consistent demands of Hengel upon New Testament scholarship that it not limit itself to the New Testament alone but that it generously include in its work the times, areas and sources before and after it; cf. his lecture as president of the International Society of New Testament scholars (SNTS): 'Aufgaben der neatestamentlichen Wissenschaft', NTS 40 (1994): 321-57 (esp. 329-31; for a summary, see ThBeitr 25 [1994]: 304-318). Cf. also 'Kein Steinbruch für Ideologien. Zentrale Aufgaben neutestamentlicher Exegese', LM 18 (1979): 23-27; 'Disziplin' (see n. 4): $25 \mathrm{f}$. His own work is an eloquent witness to the fruitfulness of this approach.

6 In the tributes to Hengel on the occasion of his seventieth birthday his accomplishments in Jewish Studies and New Testament scholarship were, as a rule, honoured separately; cf. (from the side of Jewish Studies) Peter Schäfer, 'Martin Hengel at Seventy', and (from the New Testament side) Herman Lichtenberger, 'The Tübingen School and a Tübingen Scholar', in The Beginnings of Christianity. A Collection of Articles, eds J. Pastor and M. Mor (Jerusalem: Yad Ben-Zvi Press, 2005): 21-34 and 35-41 (the lectures go back to a conference held in January 1999); for Hengel's contribution to the Gospel of John in particular, see Frey, 'Deutung' (see $n$. 3 ). These tributes supplement well the one presented here by giving greater attention to themes that I only touch on. Schäfer and Lichtenberger are also the editors of the three volume Festschrift for Hengel (see n. 2), Vol. I of which is entitled Judaism and Vol. III Early Christianity. Vol. II, Greek and Roman Religion, refers to another area of study that cannot be sufficiently acknowledged here. 
hearing the name of Hengel does not think first of The Zealots ${ }^{7}$ and Judaism and Hellenism, ${ }^{8}$ and perhaps also of the short, but much noted work Acts and the History of Earliest Christianity, ${ }^{9}$ or the vast number of mostly very lengthy articles, which, ranging from questions of the Septuagint canon ${ }^{10}$ to the Bar Kokhba War, ${ }^{11}$ appear to leave no

7 Die Zeloten was the title of Hengel's Tübingen doctoral thesis, which was submitted in 1959 and published in 1961; see Die Zeloten. Untersuchung zur jüdischen Freiheitsbewegung in der Zeit von Herodes I. Bis $70 \mathrm{n}$. Chr. (AGSU 1; Leiden: Brill, 1961). This volume marks the beginning of the series Arbeiten zur Geschichte des Spätjudentums und Urchristentums, which from vol. 8 onwards bore the more appropriate name Arbeiten zur Geschichte des antiken Judentums und des Urchristentums (the series title also therefore of the second edition in 1976), to whose editors Martin Hengel belonged for many years. It is already unusual for a doctoral work to reach a second edition; it is even more remarkable, however, that his was translated into many languages (Japanese 1986; English 1989; Italian 1996) and became a landmark study. It should not remain the only one! For the English version, see The Zealots: Investigations into the Jewish Freedom Movement in the Period from Herod I Until 70 AD, trans. D. Smith (Edinburgh: T. \& T. Clark, 1989).

8 Judentum und Hellenismus was the title of his Tübingen Habilitation in 1967, which was subsequently published as Judentum und Hellenismus: Studien zu ihrer Begegnung unter besonderer Berücksichtigung Palästinas bis zur Mitte des 2. Jh.s v. Chr. (Wissenschaftliche Untersuchungen zum Neuen Testament 10; Tübingen: Mohr, 1969). Further editions followed in 1973 and 1988 and multiple translations also appeared. This was Hengel's first publication in the series which is bound up with his name as no other, which is decisively marked by his editorial oversight (from vol. 15, 1974) and which has become one of the leading international monograph series. For John Bowden's highly acclaimed translation of Judentum und Hellenismus, see Judaism and Hellenism: Studies in their Encounter in Palestine during the Early Hellenistic Period, trans. J. Bowden (London: SCM, 1974).

9 Zur urchristlichen Geschichtsschreibung (Stuttgart: Calwer Verlag, 1979; ${ }^{2}$ 1984); Acts and the History of Earliest Christianity, trans. J. Bowden (London: SCM, 1979). An Italian translation also appeared in 1985. An important shorter essay is reprinted in the appendix to this work (Germ.: 107-13; Eng.: 127-36), which originally appeared as 'Historische Methoden und theologische Auslegung des Neuen Testaments', KuD 19 (1973): 85-90.

10 'Die Septuagint als von den Christen beanspruchte Schriftensammlung bei Justin und den Väter vor Origines' in Jews and Christians: The Parting of the Ways A.D. 70 to 135, ed. J. D. G. Dunn (WUNT 66; Tübingen: Mohr, 1992): 38-84 (= KS II: 33580); 'Die Septuaginta als "christliche Schriftensammlung", ihre Vorgeschichte und das Problem ihres Kanons' in Die Septuaginta zwischen Judentum und Christentum, eds M. Hengel and A. M. Schwemer (WUNT 72; Tübingen: Mohr, 1994): 182-284. Cf. also The Septuagint as Christian Scripture: Its Prehistory and the Problem of Its Canon, with the assistance of R. Deines, trans. M. E. Biddle (OTSt; Edinburgh: T. \& T. Clark, 2002).

11 Cf. 'Die Bar-Kokhbamünzen als politisch-religiöse Zeugnisse', Gnomon 58 (1986): 326-31 (= KS I: 344-50: extensive review of L. Mildenberg, The Coinage of the Bar Kokhba War [Aarau: Sauerländer, 1984] in which Hengel points above all to the neglected messianic component of this revolt); 'Hadrians Politik gegenüber Juden und Christen' in Ancient Studies in Memory of Elias Bickerman (New York: Columbia University Press, 1987 [= JANES 16/17 (1984/1985)]): 153-82 (= KS I: 358-91). Another article that belongs in this series of articles concerned with Jewish revolts after 
historical problem complex in the sphere of emerging Christianity untreated. Even 'Achilles in Jerusalem'12 and the 'witches of Askalon'13 are honoured with extremely learned academic treatises. But Christology? Certainly there are a few articles devoted to the topic - and both his Tübingen lecture demonstration and his inaugural lecture on 25 January $1967^{14}$ and 17 May $1975^{15}$ were dedicated to central christological questions - but can the centre and goal of the impressively extensive and learned work of Martin Hengel really be derived from Christology? The following introduction to his life's work - which is not yet concluded and which continues to bear rich fruit - should serve to draw attention to the Christological centre of Hengel's works, and,

70 is "Messianische Hoffnung und politischer "Radicalismus" in der "judischhellenistischen Diaspora". Zur Frage der Voraussetzungen des jüdischen Aufstandes unter Trajan 115-117 n. Chr'. in Apocalypticism in the Mediterranean World and the Near East: Proceedings of the International Colloquium on Apocalypticism, Uppsala, August 12-17, 1979, ed. D. Hellholm (Tübingen: Mohr, 1983; $\left.{ }^{2} 1989\right)$ : 655-86 (= KS I: 314-43).

12 Achilleus in Jerusalem. Eine spätantike Messingkanne mit Achilleus-Darstellungen aus Jerusalem, in collaboration with R. Peled (SHAP.PH 1/19821; Heidelberg: Winter, 1982). With the help of this jug, which 'demonstrates the survival of Homeric motifs in the time of the turn from the 6th to the 7th century AD', Hengel attests once more that the history of culture, thought and religion of Palestine from the time of Alexander until far into Christian late antiquity cannot be understood apart from the deep influence of Hellenism upon all areas of life. The society treatise takes its place therefore among Hengel's numerous Hellenism studies (see below n. 26 and 45), which followed Judaism and Hellenism (see n. 8). They document the lasting importance of this topic for the Jubilar and yet also beyond him. In Jewish studies in particular the question of Hellenistic influences upon Judaism has long been controversial, since with this the problem of Jewish assimilation and inculturalization is also touched upon. A good overview of the state of scholarship can be found in J. J. Collins and G. E. Sterling, eds, Hellenism in the Land of Israel (Cjan 13; Notre Dame: Univerisity of Notre Dame Press, 2001), which represents a conference held on the thirtieth anniversary of the publication of Judaism and Hellenism. Hengel himself once again summarises his position there: cf. 'Judaism and Hellenism Revisited': 6-37.

13 Rabbinische Legende und frühpharisäische Geschichte. Schimeon ben Schetach und die achtzig Hexen von Askalon (AHAW.PH 2/1984; Heidelberg: Winter, 1984).

14 Nachfolge und Charisma. Eine exegetisch-religionsgeschichtliche Studie zu Mt 8.21f. und Jesu Ruf in die Nachfolge (BZNW 34; Berlin: Töpelmann, 1968); The Charismatic Leader and his Followers, ed. J. Riches, trans. James C. G. Greig (Studies of the New Testament and Its World; Edinburgh: T. \& T. Clark, 1981). Hengel shows here that Jesus' call to discipleship cannot be isolated from his unique messianic authority (cf. esp. Germ.: 74-79; Eng.: 67-71).

15 Der Sohn Gottes. Die Entstehung der Christologie und die jüdisch-hellenistische Religionsgeschichte (Tübingen: Mohr, 1975; ${ }^{2}$ 1977); The Son of God: The Origin of Christology and the History of Jewish-Hellenistic Religion, trans. J. Bowden (London: S.C.M. Press, 1976). In retrospect this text reads like a plan of study that was carried out with astonishing tenacity in the decades that followed. 
even more, to identify this as the central thread that holds together themes that, at first glance, appear to lie so far apart. ${ }^{16}$

The Jubilar himself has made no secret of the fact that as a discriminating historian - in whose view, in spite of all methodological innovations, philology remains the proper foundation for all exact historical research - he nevertheless always sees himself first and foremost as a theologian. Correspondingly, he views New Testament scholarship as a theological discipline, which, for the sake of its object and the history and historical insight entrusted to it, is dependent upon historical research, provided that this emphasis does not degenerate into either a 'quarry for ideologies' (see n. 5), on the one hand, or merely the historical study of ancient religion, on the other. ${ }^{17}$ In his works he was and is concerned not with one truth among many but with the one Truth, which makes the sinner into a righteous person and appoints the lost person to eternal life for Jesus Christ's sake. ${ }^{18}$ In spite of all his confidence in historical study which understands historical processes, he emphatically maintains, over and against all apologetic desire-to-know-too-exactly, that one cannot prove this truth historically. But it is equally clear that he has seen himself provoked to respond where and when the message of this truth - namely that God

16 I find an element of confirmation for this judgement in a remark by Lichtenberger (see n. 6) according to which no other New Testament scholar is more predestined through his preparatory works to write a Christology of the New Testament than Hengel (40). Hengel's christological works have already been made fruitful and accessible to a wider circle in the New Testament Theology of his Tübingen colleague and friend Peter Stuhlmacher as the foreword to the first volume, which is dedicated to Hengel, and especially the index to both volumes demonstrate. Cf. P. Stuhlmacher, Biblische Theologie des Neuen Testaments I: Grundlegung. Von Jesus zu Paulus (Göttingen: Vandenhoeck \& Ruprecht, 1992): XI and 417 (Index); Vol. II: Von der Paulusschule bis zur Johannesoffenbarung (Göttingen: Vandenhoeck and Ruprecht, 1999): 370. In the meantime a third revised and expanded edition of the first volume has appeared (2005). The title of the volume of essays published together with Anna Maria Schwemer also reads like a heading for his complete works: M. Hengel and A.M. Schwemer, Der messianische Anspruch Jesu und die Anfänge der Christologie (WUNT 138; Tübingen: Mohr, 2001). Cf. also 'Vorwort', in Ibid: IX-XV.

17 'Aufgaben' (see n. 5): 349-50, 355-56. As a theologian Hengel also always knew himself to be called to the church and here he saw it as his task to remind the church that the New Testament is the fundamental and abiding witness to the foundation that supports it; cf. 'Steinbruch' (see n. 5), 25: 'What would the church be without the New Testament?'; 'Foreword' (see n. 1): viii; 'Disziplin' (see n. 4): 28.

18 For 'the question of truth', cf. 'Disziplin' (see n. 4): 22, 28; 'Aufgaben' (see n. 5): 329, 346, 349-50; 'Gentile' (see n. 4): 79-80; Lichtenberger, 'Tübingen School' (see n. 6): 35. Cf. also M. Hengel, 'Die Wahrheit als Gabe und Aufgabe', ThBeitr 1 (1970): 129-33 (Sermon on John 6:60-69). 
encounters human beings in Jesus Christ - has been declared, time and again, as obsolete on historical grounds. Against historical ignorance or distortion, he advanced, and continues to advance, a better, solid, historical judgement that finds its support in the sources. It is one of the fundamental convictions of Martin Hengel's work that the basis of the historical calling-into-question of the early Christian message and its transmission (as this was presented, for example, by Rudolf Augstein and others with great effect in the media) can and must be contradicted with solid historical-philological arguments - and also in the most public setting possible. ${ }^{19}$ For him this is part of the 'intellectual service' that the New Testament scholar owes to society and to the church.

It is characteristic for Hengel in this task that he has more confidence in 'common sense' than in the ever-more quickly changing theological and exegetical fashions and methods and their often very dogmatic claims to exclusive representation. ${ }^{20}$ At the same time he has very often been a step ahead of these fashions and methods in his own works, so that on many occasions he had already tested their performance and limits before others even took note of them: for example, he worked on the Jewish revolution and freedom movement in the 1950s when this was not in fashion - and this allowed him in the 1960s, when the call for a political theology was raised, to show the historical and theological limits of the attempts to answer this call by repeatedly pointing out the problematic character of the New Testament borrowings and justifications involved. ${ }^{21}$ The christological

19 In these rejoinders and refutations Hengel shows himself to be a master of sharp language; cf. 'Augstein und der Menschensohn', EK 5 (1972): 666-70; 'Die Qumranrollen und der Umgang mit der Wahrheit', EK 23 (1992): 233-37 (Review of M. Baigent/R. Leigh, Verschlußsache Jesus: Die Qumranrollen und die Wahrheit über das frühe Christentum (München: Droemer Knaur, 1991); Abbreviated version in the FAZ on 10.1.1992); 'Ein Journalist träumte, er sei Pilatus ...', EK 23 (1992) 333-336 (Review of J. V. Uthmann, Pontius Pilatus. Ein Briefwechsel [Hamburg: Hoffmann u. Campe, 1991]; abbreviated version in the Rheinischen Merkur on 19.6.1992); 'Ein Blick zurück im Zorn', ThBeitr 32 (2001), 65-69 (On the new edition of R. Augstein, Jesus Menschensohn (Hamburg: Hoffmann und Campe, 1999).

20 'Disziplin' (see n. 4): 20-21, 28-29; see also the next note.

21 Only a selection of the relevant contributions can be mentioned here as evidence: 'War Jesus Revolutionär? Sechs Thesen eines Neutestamentlers', EK 2 (1969): 694-96; War Jesus Revolutionär? (CwH 110; Stuttgart: Calwer, 1970; 2nd edition 1970; ${ }^{3} 1971$; ${ }^{4} 1973$ ); Was Jesus a Revolutionist?, trans. W. Klassen (Philadelphia: Fortress, 1971); Gewalt und Gewaltlosigkeit: Zur 'politischen Theologie' in neutestamentlicher Zeit (CwH 118; Stuttgart: Calwer, 1971); Victory over Violence: Jesus and the Revolutionists, trans. D. E. Green (Philadelphia: Fortress Press, 1973); "Politische Theologie" und Zeitgeschichte', KuD 18 (1972): 18-25; Christus und die Macht. Die 
centre was also never absent for Hengel in these topical confrontations because, in his view, argumentation that is Christian and theological can find its criterion only in Jesus Christ. ${ }^{22}$

In other areas he was also before his time: before feminist exegesis had advanced its claims Hengel occupied himself with the topic of women as the first Easter witnesses, ${ }^{23}$ and before social-historical questions became commonplace he presented a series of substantial studies that had a social-historical orientation. ${ }^{24}$ These questions were

Macht Christi und die Ohmacht der Christen. Zur Problematik einer "Politische Theologie” in der Geschicht der Kirche (Stuttgart: Calwer, 1974); Christ and Power, trans. E.R. Kalin (Belfast: Christian Journals, 1977). The fact that the two longer lectures in the Calwer pamphlets were translated into numerous languages (and the last book, at least, into English) shows that the relevance of these confrontations with topical social questions extended (and extend) far beyond their own immediate context. Solid historical research becomes outdated much less frequently than what is owed merely to the Zeitgeist. Cf. also 'Wider den politischen Mißbrauch der Bergpredigt', in Abschaffung des Krieges, eds G. Brakelmann and E. Müller (GTBS 1077; Gütersloh: Mohn, 1983): 44-51; cf. also Frey, 'Deutung' (see n. 3): 348.

22 Cf. the short sketch of Jesus' activity in Revolutionist (see n. 21): 19-35, which concludes with the words: "The truth does not lie in our "interpreting" the figure of Jesus to accord with the latest fashion of our time - a process in which "interpreting" all too easily becomes a falsifying; but truth lies in this, that our life is molded and fashioned by him.' The anti-revolutionary or radical revolutionary love message is at the same time not to be separated from his 'messianic claim' (Violence [see n. 21]: 44). Cf. Revolutionär (see n. 21 [1970]): 16-25, 35-47; Gewalt (see n. 21): 43.

23 'Maria Magdalena und die Frauen als Zeugen', in Abraham unser Vater: Jüden und Christen im Gespräch über die Bible, FS O. Michel, eds O. Betz, M. Hengel and P. Schmidt (AGSU 5; Leiden: Brill, 1963): 243-56. Here Maria Magdalena is placed on the same level as Peter as an Easter witness. All the uproar caused by the media marketing of the apocryphal gospel of Mary Magdalene, including Dan Brown's Da Vinci Code, is basically already anticipated in this article on one page (251).

24 In Germany Gerd Theißen has above all emerged as a proponent of a social history of Early Christianity; his works on this topic have appeared since 1973 and are collected in G. Theißen, Studien zur Soziologie des Urchristentums (WUNT 19; Tübingen: Mohr, 1979; 1989). In the foreword to this volume he expressly thanks M. Hengel, 'who promoted both the emergence of particular articles and this collection of articles' (VI). The important collection of essays edited by Wayne Meeks also first appeared in 1979. Cf. W. Meeks, ed., Zur Soziologie des Urchristentums (ThB 62; München: Kaiser, 1979). The following works by Hengel were already available: 'Das Gleichnis von den Weingärtnern Mark 12:1-12 in Lichte der Zenonpapyri und der rabbinischen Gleichnisse', ZNW 59 (1968): 1-39 (here the social-historical analysis contributes to the understanding of the picture element of the parable whose christological point is only then felt (cf. 37-38); for this parable, see now John S. Kloppenborg, The Tenants in the Vineyard: Ideology, Economics, and Agrarian Conflict in Jewish Palestine [WUNT 195; Tübingen: Mohr, 2006], where the socialhistorical interpretation shown by Hengel is developed further in a consistent and materially rich manner); Eigentum und Reichtum in der frühen Kirche: Aspekte einer frühchristlichen Sozialgeschichte (Stuttgart: Calwer, 1973); Property and Riches in the Early Church, trans. J. Bowden (London: SCM). In addition to this his works relating 
pressed on him not by an ideological substructure or superstructure, but by 'the reality of history'. ${ }^{25}$ As he puts it, 'For the sake of historical realities the historian must attempt to grasp human beings in the entirety of their life situations.' ${ }^{26}$ Access to historical reality is mediated, prior to all methods, by the sources; for Hengel these sources include, alongside the written records ${ }^{27}$ - which he has studied with passion and an untiring joy in discovery - archeological and geographical findings. ${ }^{28}$ For him it is a part of subject-appropriate under-

to the Jewish freedom movement and those mentioned in $\mathrm{n} .45$ also belong in a wider sense to the social history of early Judaism and emerging Christianity.

25 'Disziplin' (see n. 4): 22; Aufgabe (see n. 5): 337 n. 47, where Hengel makes a criticism of German theology his own according to which 'contact with reality ... was not considered to be either useful or necessary'. This situation, however, has clearly improved in meantime, not least due to the influence of Hengel.

26 'Die Begegnung von Judentum und Hellenismus im Palästina der vorchristlichen Zeit' in Verborum Veritas, FS G. Stählin, eds O. Böcher and K. Haacker (Wuppertal: Brockhaus, 1970): 329-48 (= KS I: 151-70; citation: 347 and 169). This article presents a concise summary of Judaism and Hellenism (see n. 8).

27 That this insistence on sources, sources and sources yet again was successful among his students at least and left a deep impression is shown independently by the two Hengel-students Reinhard Feldmeier ('Anwalt des Anderen': 128-134, esp. 130) and Jörg Frey ("“Texte, Texte und nochmals Texte" - Vom Lesen des Neuen Testaments zur neutestamentliche Wissenschaft': 225-35, esp. 226) in their autobiographical essays in the edited volume mentioned in n. 4. The works of these and other students of Martin Hengel gives some idea of the contagious fascination elicited by his own engagement with the sources.

28 Here a personal note may be allowed: whenever I told Prof. Hengel of my travels and tours I was always surprised afresh by his precise knowledge of the ancient and contemporary geography of the 'holy lands' of Early Christianity (Israel, Egypt, Syria, Asia Minor, Greece, Italy). Although he himself is not a great traveller, he knew all about the transportation details and when I recounted where I had been, then the question immediately arose whether I had seen this inscription or that temple or whether I had made an excursion to an important neighbouring locale. This extensive knowledge was apparently always at his fingertips. Sometimes I had the impression that he rather than I had made himself familiar with the travel route and read all the interesting facts about it. And yet this is nothing other than an expression of his respect (one can almost even say his reverence) for the reality to which also the geography belongs. That this 'concrete' geographical conception also became exegetically fruitful is shown by - alongside the many lengthy footnotes and excursuses in his larger works (especially prominent in M. Hengel and A. M. Schwemer, Paulus zwischen Damaskus und Antiochien: Die unbekannten Jahre des Apostels [WUNT 108; Tübingen: Mohr, 1998]; Martin Hengel and Anna Maria Schwemer, Paul Between Damascus and Antioch: The Unknown Years [London: SCM, 1997]) - the two articles 'Der Historiker Lukas und die Geographie Palästinas in der Apostelgeschichte', ZDPV 99 (1983): 14783; 'Luke as Geographer and Historian' in Between Jesus and Paul: Studies in the Earliest History of Christianity, trans. J. Bowden (London: SCM, 1983): 87-132, 190210, and 'Iouo $\alpha \dot{\alpha} \alpha$ in der geographischen Liste Apg 2,9-11 und Syrien als "Großjudäa", $R H P h R 80$ (2000): 51-68. 
standing ${ }^{*}$ to know, as far as possible, all the available sources (not, by contrast, all the secondary literature) that are relevant to the historical or exegetical question that is to be investigated, and not merely the philosophical or methodological vocabulary that is currently in vogue. This makes the majority of his works timeless classics that have understandably undergone many translations. Future generations of students and researchers will continue to be able to work away at them with great fruit, thanks to their learning, their material abundance and the many stimulating proposals they contain. ${ }^{29}$ The presupposition here, however, is the now diminishing ability and readiness to stand before the complexity and diversity of a topic and to take note first of the available facts before one comes to a judgement. For the exegete and historian Hengel, who as such has always remained a theologian, the ability to exercise historical judgement is the foundation for the proper formation of theological judgements. For this reason, theological positions without exegetical-historical substance elicit his disapproval just as much as exegesis which is exclusively occupied with historical criticism and therefore no longer prepared to reflect upon its relevance for theology.

The path to this outlook led, in addition to the formative influence of his family and the experiences of the War, above all, as Hengel himself repeatedly emphasises in countless discussions, via the Tübingen Stift where he became a 'Stiftsrepetent' in 1954. His colleagues at that time (with the exception of his friend Otto Betz, with whom he has shared a lifelong friendship ${ }^{30}$ ) were in his own words 'drunk with sweet wine from Marburg', ${ }^{31}$ as served, above all, by Rudolf Bultmann, who at that time, in the mid-1950s, was at the height of his influence. Hengel's protest was elicited in particular by the assertion of a non-

\footnotetext{
* 'sachgemäßen Verstehen'.

29 As an example reference may be made to his already mentioned Tübingen inaugural lecture (Sohn Gottes; The Son of God [see n. 15]). The collection of texts there and the reference to 'Vielnamigkeit' (the coexistence of many names) as a christological program has thus far not been taken up, even if many recent works on the christological titles have long since broken away from the all too rigid schematism that characterised the classic works in the sixties and seventies and have more clearly recognised their 'accumulative' character (Germ.: 90; Eng.: 57).

30 Cf. Hengel's tribute to his old friend in 'Reichtum des biblischen Wortes: Dem Judaisten und Neutestamentlicher Otto Betz zum 70 Geburtstag', ThLZ 112 (1987): 701f.; even more personal is Hengel's forward in Otto Betz, Jesus Der Messias Israels: Aufsätze zur biblischen Theologie (WUNT 42; Tübingen: Mohr, 1987): V-VII.

31 'Disziplin' (see note 4): 20.
} 
messianic Jesus, whose proclamation and life were not the actual content of the gospel but instead presented only its - historically given and yet theologically dispensable - prehistory. Bultmann's claim that one 'does not need to get further than' the 'that' of Jesus' coming, because Paul and John also gave 'no picture of the historical Jesus and his proclamation', since for them 'as a historical fact only Jesus' crucifixion was significant', ${ }^{32}$ has constituted, in a way, the point of departure for Hengel's works up until the present. ${ }^{33}$

Already in his very first publication Hengel interpreted the healings of Jesus and the call to faith that came to expression in them (Mark 9:23) as 'indissolubly bound up with his messianic sending and the message of the approaching reign of God' ${ }^{34}$ His engagement with the Zealots as a movement that can only be understood in relation to messianic expectations served to clarify further the particular and unique form of expression that Jesus gave to the messianic

32 R. Bultmann, 'Das Verhältnis des urchristlichen Christuskerygmas zum historischen Jesus' in Der historische Jesus und der kerygmatische Christus, eds H. Ristow and H. Matthiae (Berlin: Evangelische, 1962): 233-35, esp. 233. Bultmann's article is the summary of his famous Heidelberg Society lecture delivered in 1959, in which he once more made his position clear over against his own circle of students (Das Verhältnis der urchristlichen Christusbotschaft zum historischen Jesus [SHAW.PH 3/1960: Heidelberg: Winter, $\left.1960\left({ }^{4} 1965\right)\right]$ : 5-27; also in R. Bultmann, Exegetica, ed. E. Dinkler [Tübingen: Mohr, 1967]: 445-69). Since the start of the fifties a renewed inquiry had begun here into the meaning of the historical Jesus, which Bultmann rejected. The collection of essays edited by Ristow/Matthiae offers a good view into the controversies of this period.

33 The following recent works may be noted: 'Das Begräbnis Jesu bei Paulus und die leibliche Auferstehung aus dem Grabe' in Auferstehung - Resurrection: The Fourth Durham - Tübingen Research Symposium (Tübingen, September 1999), ed. F. Avemarie and H. Lichtenberger (WUNT 135; Tübingen: Mohr, 2001): 119-83; 'Das Mahl in der Nacht "in der Jesus ausgeliefert wurde" (1 Kor 11:23)' in Le repas de Dieu. Das Mahl Gottes, 4. Symposium Strasbourg, Tübingen, Upsal, Strasbourg 11-15 Septembre 2002, ed. C. Grappe (WUNT 169; Tübingen: Mohr, 2004): 115-60; 'Abba, Maranatha, Hosanna und die Anfänge der Christologie', in Denkwürdiges Geheihmis. Beiträge zur Gotteslehre, FS E. Jüngel, ed. I. U. Dalferth et al. (Tübingen: Mohr, 2004): 145-83; 'Eye-witness memory and the writing of the Gospels: Form criticism, community tradition and the authority of the authors', trans. W. Coppins, in The Written Gospel, FS G. N. Stanton, eds M. Bockmuehl and D. A. Hagner (Cambridge: Cambridge University Press, 2005): 70-96.

34 'Die Heilungen Jesu und medizinisches Denken' in Medicus Viator, FS Richard Siebeck, eds P. Christian and D. Rössler (Tübingen: Mohr, 1959): 331-61; reprinted in Der Wunderbegriff im Neuen Testament, ed. A. Suhl (WdF 295; Darmstadt: Wissenschaft. Buchges., 1980): 338-73 (361). The co-author of this article was the medical doctor Rudolf Hengel, the older brother of Martin Hengel. 
expectation..$^{35}$ The readiness for martyrdom among the Zealots, including religious suicide and the theological conceptions bound up with it, ${ }^{36}$ formed the point of departure for his fundamental and much noted studies on the punishment of crucifixion in the ancient world and Jesus' conscious taking upon himself of the 'mors turpissima' as an atonement for the sins of the world. ${ }^{37}$ These studies were preceded by the previously mentioned works on 'the charismatic leader and his followers' and 'the Son of God', which both circled around Jesus' messianic status. While The Charismatic Leader and his Followers was concerned with the continuity between Jesus' earthly activity and the early Christian proclamation about him, The Son of God served in particular to refute the derivation of this title from so-called Hellenistic Christianity with its supposedly syncretistic tendencies ${ }^{38}$ as well as its compatibility with Jesus' messianic 'claim to full authority' (Sohn Gottes p. 139). Against the (mis)understanding of Christianity as a

35 Zeloten (see n. 7): 306-07; 385-86; Zealots (see n. 7): 300-02; 378-79; see also the other relevant works mentioned in $\mathrm{n} .11$ and 'Vorwort' (see n. 16): XII-XIII.

36 Zeloten (see n. 7): 261-77; Zealots (see n. 7): 256-71. For the atoning power of the martyr's death, see 273 (Germ.); 267-68 (Eng.). For the application with reference to 2 Cor. 5:18-21, see 'Der Kreuzestod Jesu Christi als Gottes souveräne Erlösungstat. Exegese über 2 Korinther 5:11-21' in Theologie und Kirche. Reichenau-Gespräch, ed. Der Evangelischen Landessynode in Würrtemberg (Stuttgart: Calwer, 1967): 60-89 esp. 73-77.

37 "Mors turpissima crucis. Die Kreuzigung in der antiken Welt und "Torheit" des "Wortes vom Kreuz"“, in Rechtfertigung, FS E. Käsemann, ed., J. Friedrich et al. (Tübingen: Mohr, 1976): 125-84 (often translated and expanded and reprinted many times in English); 'Der stellvertretende Sühnetod Jesu. Ein Beitrag zur Entstehung des urchristlichen Kerygmas', IKZ 9 (1980): 1-25. 135-47 (there are also numerous translations of this work); The English edition, which has also often been reprinted, is considerably expanded over against the German: The Atonement. A Study of the Origins of the Doctrine in the New Testament, trans J. Bowden (Philadelphia: Fortress Press, 1981). For the English version of 'Mors turpissima crucis', see Crucifixion in the Ancient World and the Folly of the Message of the Cross, trans. J. Bowden (London: SCM, 1977).

38 Sohn Gottes (see n. 15): 32-34 (and often); The Son of God (see n. 15): 17-19; cf. here the citation from R. Bultmann, 'Das christliche Bekenntnis des Ökumenischen Rates', EvTh 6 (1951/1952): 1-13 or SthU 20 (1951): 25-36, which is also in R. Bultmann, Glauben und Verstehen II (Tübingen: Mohr, $\left.{ }^{5} 1968\right)$ : 246-61, esp. 251: 'For the figure of a son-deity suffering and dying and raised again to life is also known to the mystery religions, and Gnosticism above all is aware of the notion of the Son of God become man - of the heavenly redeemer become man' (Eng. 18; cf. Germ.: 33). Against the assertion that there was a pre-Christian Gnosis, see M. Hengel, 'Die Ursprünge der Gnosis und das Urchristentum' in Evangelium - Schriftauslegung Kirche, FS P. Stuhlmacher, eds, J. Ådna et al. (Göttingen: Vandenhoeck \& Ruprecht, 1997): 190-223; 'Paulus und die Frage einer vorchristlichen Gnosis', KS III: 473-510. This latter text also contains many methodological observations, since the Gnosis question is always also a question concerning the assessment of the sources. 
syncretistic religion Hengel increasingly emphasised the derivation of all essential elements from the contemporary, admittedly 'hellenised' Judaism. ${ }^{39}$ With respect to the christological titles as well, on which Hengel also presented a series of important studies, ${ }^{40}$ no borrowings from outside of Judaism are necessary to make intelligible either their use by Jesus himself or their application to him as an expression already of the authority and dignity of the earthly Jesus; ${ }^{41}$ furthermore, such borrowings cannot be made historically probable. For the first heralds and shapers of the early Christian message were the travel companions of the man from Nazareth, who were with him in Galilee and went with him to Jerusalem, where they were witnesses of his condemnation and execution and yet also of his resurrection. These men and women who knew Jesus and were close to him gave content and form to the gospel of Jesus Christ.

39 For a concise summary, see 'Das früheste Christentum als eine Jüdische messianische und universalistische Bewegung', ThBeitr 28 (1997): 197-210 (= KS II: 200-18). For the expanded English version, see 'Early Christianity as a JewishMessianic Universalist Movement', in M. Hengel/C. K. Barrett, Conflicts and Challenges in Early Christianity, ed. D. A. Hagner (Harrisburg: Trinity, 1999): 1-41; cf. 'Disziplin' (see n. 4): 22.

40 A compact summary of his Christology, whose positions regarding particular titles were pursued further in numerous subsequent articles, is the much-too-little-noted article 'Die christologischen Hoheitstitel im Urchristentum. Der gekreuzigte Gottessohn', in Der Name Gottes, ed. H. v. Stietencron (Düsseldorf: Patmos, 1975): 90-111; 'Christological Titles in Early Christianity', in Studies (see n. 1): 359-89; cf. also 'Jesus als messianischer Lehrer der Weisheit und die Anfänge der Christologie', in Der messianische Anspruch Jesu (see n. 16): 81-131 (expanded version of a lecture held in 1976 and first published in 1979); 'Jesus as Messianic Teacher of Wisdom and the Beginnings of Christology', in Studies (see n. 1): 73-117; 'Erwägung zum Sprach-

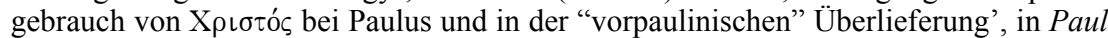
and Paulinism, FS C. K. Barrett, eds M.D. Hooker and S.G. Wilson (London: SPCK, 1982), 135-159 (= KS III: 240-61); "“Christos” in Paul' in Between Jesus and Paul (see n. 28): 65-77; “"Setze dich zu meiner Rechten!” Die Inthronisation Christi zur Rechten Gottes und Psalm 110:1', in Le Trône de Dieu, ed., M. Philonenko (WUNT; Tübingen: Mohr, 1993): 108-94; "Sit at My Right Hand": The Enthronement of Christ at the Right Hand of God and Psalm 110:1', in Studies (see n. 1): 119-225; 'Zur Wirkungsgeschichte Von Jes 53 in Vorchristlicher Zeit' in Der Leidende Gottesknecht. Jesaja 53 Und Seine Wirkungsgeschichte, eds B. Janowski and P. Stuhlmacher (FAT 14; Tübingen: Mohr, 1996): 49-91 (=KS II: 72-114); for further works, see n. 43f. and 49.

41 Cf. by contrast H. Conzelmann/A. Lindemann, Arbeitsbuch zum Neuen Testament (thirteenth edition 2000; Tübingen: Mohr, 1975) in which $\S 56$ on the 'Inquiry into Jesus' Self-Awareness' maintains the position in a single-minded manner throughout all its editions that 'Jesus did not use any of the christological titles mentioned in the Synoptic gospels with reference to his own person' for which reason it is impossible 'to reconstruct Jesus self-awareness from the christological titles' (2000: 495; cf. 1975: 372). The 2000 edition also denies that were 'many messianic pretenders' in Jesus' day: 489 . 
That Jesus is the Messiah of Israel, whose deed of salvation also encompasses the peoples of the world, was known by his Jewish disciples, ${ }^{42}$ and this understanding was thought through and formulated on the basis of what was learned from him and what was experienced with him, whereby the hymnic glorification of the divine mystery ${ }^{43}$ preceded its notional penetration. But neither the sources nor the chronological facts allow for the often alleged development from a simple, eschatological prophet conception in the early Palestinian community to a Son of God and Kyrios Christology constructed according to a pagan model. ${ }^{44}$ The religio-historical construct of a Hellenistic-syncretistic distortion of the originally 'simple' gospel of Jesus is, as it were, refuted from all sides by Hengel. In this way, he has been able, through his numerous works on the hellenising of Palestinian Judaism - undertaken with great effort and care - to serve the cause of a subject-appropriate understanding of the historical enablement of the christological development. ${ }^{45}$ These studies form in

42 In the discovery of the 'universal' potential of the messianic work of Jesus the 'Hellenists' of Jerusalem prepared the ground for the work of Paul; nevertheless, this reaching beyond the boundaries of the Jewish people would not have been possible without beginnings in the activity of Jesus himself. For these transitions, see the fundamental articles 'Die Ursprünge der christlichen Mission', NTS 18 (1971/1972): 15-38; 'The Origins of the Christian Mission' in Between Jesus and Paul (see n. 28): 48-64; 'Zwischen Jesus und Paulus. Die "Hellenisten", die "Sieben" und Stephanus (Apg 6:115; 7:54-8:3)', ZThK 72 (1975): 151-206 (with additions in KS III: 1-67); 'Between Jesus and Paul: The "Hellenists", the "Seven" and Stephen (Acts 6:1-15; 7:54-8:3)' in Between Jesus and Paul (see n. 28): 1-29. Cf. as well the article listed in n. 44. Cf. now also F. Wilk, Jesus und die Völker in der Sicht der Synoptiker (BZNW 109; Berlin: de Gruyter, 2002).

43 Cf. 'Hoheitstitel im Urchristentum' (see n. 40); 'Christological Titles' (see n. 40); 'Hymnus und Christologie' in Wort in der Zeit, FS K.H. Rengstorf, ed. W. Haubeck and M. Bachmann (Leiden: Brill, 1980), 1-23; 'Hymns and Christology' in Between Jesus and Paul (see n. 28), 78-96; 'Das Christuslied im frühesten Gottesdienst' in Weisheit Gottes - Weisheit der Welt, FS Joseph Kardinal Ratzinger, vol. 1, ed. W. Baier et al. (St. Ottilien: EOS-Verlag, 1987): 357-404; 'The Song about Christ in Earliest Worship' in Studies (see n. 1): 227-91.

44 See 'Christologie und neutestamentliche Chronologie. $\mathrm{Zu}$ einer Aporie in der Geschichte des Urchristentums' in Neues Testament und Geschichte, FS O. Cullmann, eds O. Baltensweiler and B. Reicke (Tübingen: Mohr, 1972): 42-67; 'Christology and New Testament Chronology: A Problem in the History of Earliest Christianity' in Between Jesus and Paul (see n. 28): 30-47.

45 In addition to the works already mentioned (see n. 8 and 12) see Juden, Griechen und Barbaren. Aspekte der Hellenisierung des Judentums in vorchristlicher Zeit (SBS 76; Stuttgart: Katholisches Bibelwerk, 1976); Jews, Greeks and Barbarians: Aspects of the Hellenization of Judaism in the pre-Christian Period, trans. J. Bowden (Philadelphia: Fortress, 1980); 'Qumrân und der Hellenismus' in Qumrân: sa piété, sa théologie et son milieu, ed. M. Delcor (BEThL 46; Paris: Duculot, 1978): 333-72 (=KS 
his complete works the indispensable historical substructure; the only reason their meaning for Christology 46 is not seen so clearly today is that his results have in the meantime become to a large extent the common position of scholarship. ${ }^{47}$ The later development of Christology, if one follows in Hengel's footsteps, proves to be not a heathenising or mythologising of Jesus but rather a proper explication of what Jesus was, did and intended. ${ }^{48}$ The fact that his most summarising article thus far on 'Jesus, the Messiah of Israel' 49 originally appeared in the Festschrift for the Jewish scholar of religion David Flusser shows

I, 258-94); 'Zum Problem der "Hellenisierung” Judäas im 1. Jahrhundert nach Christus (KS I: 1-90); The 'Hellenization' of Judaea in the First Century after Christ, in collaboration with Chr. Markschies, trans. J. Bowden (London: SCM, 1989); 'Jerusalem als jüdische und hellenistische Stadt' in Hellenismus. Beiträge zur Erforschung von Akkulturation und politischer Ordnung in den Staaten des hellenistischen Zeitalters, ed. B. Funck (Tübingen: Mohr, 1996): 269-306 (= KS II: 115-56); 'Qumran and Hellenism' in Religion in the Dead Sea Scrolls, eds J. J. Collins and R. A. Kugler (Grand Rapids: Eerdmanns, 2000): 46-56.

46 Hengel himself has also named the historical consequences of his historical research. Cf. 'The Hellenisierung des antiken Judentums als Praeparatio Evangelica', Humanistische Bildung Heft 4 (1981): 1-30 (= KS I: 295-313 [together with Hermann Lichtenberger, his then assistant and later successor to the Tübingen chair]); Judentum und Hellenismus (see n. 8): 569-70; Judaism and Hellenism (see n. 8): 313-14; 'Hellenisierung' (see n. 45): 1-12, 85-90; Hellenization (see n. 45): 1-6, 53-56.

47 But cf. above n. 41. The study book by Conzelmann/Lindemann represents (and revives) in contemporary discussion the positions influenced by Bultmann that Hengel opposes. In this book therefore an alleged origin from 'Hellenistic Christianity' is still used as an argument for authenticity and dating in that for the 'reconstruction of the pre-Pauline Hellenistic Christianity' statements are to be drawn upon, which 'in Pauline and non-Pauline writings are naturally presented as Christian statements but which cannot be attributed to the primitive Jerusalem community since they are Hellenistically colored' (1975: 402f. $=1983$ : 415f. $[\S 65$ is entitled 'Hellenistic Christianity and the Beginning of Paul's Activity']). Behind this stands the simple system: what is Hellenistic cannot go back to the primitive Jerusalem church and certainly not to the historical Jesus. Despite significant changes in the 2000 edition ( $\S$ 65 is now entitled 'Early Hellenistic Christianity and the Problem of Syncretism'), the basic statement is the same: Paul found 'Christianity as an already 'syncretic entity influenced not only by Judaism but also by non-Jewish Hellenism' (541).

48 For New Testament scholarship the Edinburgh New Testament scholar Larry W. Hurtado should above all be mentioned, who has thus far most strongly further developed Hengel's insights into an impressive presentation of the whole. In particular, Hengel's programmatic article on the chronology of the christological development (see n. 44) pointed the way forward for Hurtado; cf. L. Hurtado, Lord Jesus Christ. Devotion to Jesus in Earliest Christianity (Grand Rapids: Eerdmanns, 2003): 2 n. 4, 707 (Index). Hengel is among the authors who are mentioned most by a wide margin.

49 'Jesus der Messias Israels' in Messiah and Christos: Studies on the Jewish Origin of Christianity, FS D. Flusser, ed. I. Gruenwald et al. (TSAJ 32; Tübingen: Mohr, 1992): 155-76; substantially expanded in 'Der messianische Anspruch Jesu (see n. 16): 1-80. For the English version, see 'Jesus, the Messiah of Israel' in Studies (see n. 1): 172. This volume also contains many other important christological articles. 
that with his research Martin Hengel not only wishes to serve Christian theology and the church but that he also makes an effort to obtain a subject-appropriate understanding of Jesus and his message within Jewish scholarship.

Martin Hengel's sustained engagement with the great and formative figures of early Christianity, ranging from Mary Magdalene to Peter, also contributes to his effort to obtain a subject-appropriate understanding of the development of early Christian Christology. For, historically speaking, it is these figures who form the bridge between the earthly Jesus and the proclaimed message of salvation whose centre is Jesus himself. Between the proclaimer and the proclaimed there are neither dark years of hidden tradition formation nor numerous unknown communities, groups, anonymous tradents and anonymous collectors - as classic form criticism assumed - but rather formative individual figures with far reaching personal magnetism, whose authority lies in their closeness to Jesus or, as in the case of Paul, in the unique history of their calling. Among them Peter stands out in view of his importance for both the synoptic Jesus tradition and the transmission of the Jesus message to Paul..$^{50}$ Next to him are the great figures of John the Presbyter, who in Hengel's view is a Jerusalem disciple of Jesus, ${ }^{51}$ and James the natural brother of Jesus, ${ }^{52}$ who,

50 The numerous scattered references to Peter are now brought together in Der unterschätzte Petrus: Zwei Studien (Tübingen: Mohr, 2006). For the significance of Peter for Paul, see Geschichtsschreibung (see n. 9): 74-76 (see also 79-84); Acts (see n. 9): 85-87 (see also 92-98); Paulus zwischen Damaskus und Antiochien (see n. 28): 214-36; Paul between Damascus and Antioch (see n. 28): 133-50. For Peter's link with the synoptic tradition, see esp. Hengel's studies on the Gospel of Mark: 'Probleme des Markusevangeliums' in Das Evangelium und die Evangelien, ed. P. Stuhlmacher (WUNT 28; Tübingen: Mohr, 1983): 221-65; 'Entstehungszeit und Situation des Markusevangeliums' in Markus Philologie, ed. H. Cancik (WUNT 33; Tübingen: Mohr, 1984): 1-45; cf. also The Four Gospels and the One Gospel of Jesus Christ (London: SCM, 2000): 78-96.

51 Die johanneische Frage. Ein Lösungsversuch. Mit einem Beitrag zur Apokalypse von Jörg Frey (WUNT 67; Tübingen: Mohr, 1993): esp. 275-325; The Johannine Question (London: SCM Press; Philadelphia: Trinity Press International, 1989): esp. 109-35.

52 'Jakobus der Herrenbruder - der erste "Papst"?' in Glaube und Eschatologie, FS W.G. Kümmel, eds E. Gräßer and O. Merk (Tübingen: Mohr, 1985): 71-104 (= KS III: 549-82); 'Der Jakobusbrief als antipaulinische Polemik' in Tradition and Interpretation in the New Testament, FS E. Ellis, eds G. F. Hawthorne and O. Betz (Grand Rapids: Eerdmanns, 1987): 247-78 (revised and expanded in KS III: 511-48). The conflict with James and the wing of the early church represented by him also receives extensive treatment in Hengel's books on Peter and Paul; cf. e.g., Paulus zwischen Damaskus und Antiochien (see n. 28): 217-18, 221-23, 383-89; Paul between Damascus and Antioch (see n. 28): 135-36, 138-40, 257-60. 
together with Paul - who himself cannot be understood without the Jerusalem tradition - vouch for the continuity between the time before and after Easter. A further fundamental characteristic in Hengel's presentation of the history of early Christianity is that these great and formative figures stand in personal, if also often strained, relationship with one another so that their proclamation and their formation of the gospel did not take place in 'splendid isolation' from one another. The communities and their leading representatives still knew each other and were in contact with one another so that there is ultimately one though multifaceted and reflected differently in the presuppositions of its witnesses - Christology, which is handed down in the New Testament and entrusted to the church of Jesus Christ for preservation and passing on.

At the end of this article - which, in view of the breadth of the Jubilar's work, is all too brief - it remains only to point to what has been passed over: Martin Hengel is not only a truly great teacher, but also a constant learner, whose admiration is accorded to a list of scholars stretching from Clement of Alexandria into the present. His numerous biographical studies and works on the history of scholarship along with the reviews and prefaces he has written would be worth a volume of their own in his 'shorter writings'. In the laudations from his pen the work of his colleagues has been recognised with thankfulness and often with deep attachment. His contribution to Jewish-Christian dialogue, too, has up until now hardly been recognised and appreciated as it deserves. ${ }^{53} \mathrm{He}$ made it possible for friendships to arise from collegial relationships with the result that Jewish and Christian scholars came to know and appreciate one another. And through his efforts the boundaries between the study of the New Testament and the study of early Judaism have become more permeable. His studies devoted wholly to the history of Judaism have won him trust and support, and this not least because he did not attempt, as much as he was engaged in historical work, to conceal his own calling as a Christian theologian. He has remained faithful to his own course in an unwavering manner: for one he is not historical enough because he is too theological; for another he is still too critical because he is not sufficiently loyal to the Bible. With his knowledge, his tireless commitment to every good

53 For his accomplishment for Jewish studies, see Schäfer, 'Martin Hengel' (see n. 6).

* weil zu wenig 'bibeltreu'. 
academic project irrespective of its 'camp' of origin, and his contagious passion for the texts that are to be understood, he nevertheless continues to cultivate personal contacts, despite all supposed and real limits, which are documented in thousands of letters, references, marginal notes to manuscripts, and forewords. Beyond this, innumerable people who have sought to hear his opinion or to solicit his advice are indebted to him for valuable suggestions in discussion, telephone conversations, visits and invitations. His significance for New Testament scholarship is thus evident not only in his publications but also in the fact that he is also there for others as friend, teacher, father, example, counsellor and intercessor. May many more rich years of fruitful activity be granted to him! 